Breeding and Feeding the High Genetic Merit Dairy Cow

Occasional Publication No. 19 - British Society of Animal Science 1995

edited by T. L. J. Lawrence, F. J. Gordon and A. Carson

\title{
Urea as a source of effective rumen degradable protein for high-yielding dairy cows
}

\author{
R. J. Mansbridge ${ }^{1}$ and E. R. Deaville ${ }^{2}$ \\ ${ }^{1}$ ADAS Bridgets Research Centre, Martyr Worthy, Winchester Hampshire SO21 1AP \\ ${ }^{2} A D A S$ Feed Evaluation Unit, Alcester Road, Stratford-upon-Avon CV37 9RQ
}

\section{Introduction}

The Agricultural and Food Research Council (ARFC, 1992) suggests that the ratio of effective rumen degradable protein (ERDP) to fermentable metabolizable energy (FME) should be at least $11.5 \mathrm{~g} / \mathrm{MJ}$ FME for dairy cows yielding above $40 \mathrm{~kg} /$ day. The work reported here was carried out to determine the effect of increasing the calculated ERDP : FME ratio on dry-matter (DM) intake and milk production.

\section{Material and methods}

Twenty freshly calved Holstein cows were allocated to one of two complete diets (control $(\mathrm{C})$ or test $(\mathrm{T})$ ) both based on maize and grass silage $(0 \cdot 75: 0.25 \mathrm{DM}$ basis). The diets were formulated to meet the metabolizable energy (ME) requirements (AFRC, 1990) for $45 \mathrm{~kg}$ milk per day and to supply metabolizable protein (MP) at proportionately 0.1 above current recommendations (AFRC, 1992). Silage analyses for the grass and maize silages respectively were: corrected dry matter (CDM) (oven dry matter +1.9 units) $281,320 \mathrm{~g} / \mathrm{kg}$; $\mathrm{pH} 3.9,3.7$; crude protein (CP) $148,75 \mathrm{~g} / \mathrm{kg}$ CDM; neutral-detergent fibre (NDF) $534,548 \mathrm{~g} / \mathrm{kg} \mathrm{CDM}$, estimated ME 11.3, $11.0 \mathrm{MJ} / \mathrm{kg} \mathrm{CDM}$ and estimated FME $8.6,8.6 \mathrm{MJ} / \mathrm{kg}$ $\mathrm{CDM}$. The starch content of the maize silage was $256 \mathrm{~g} / \mathrm{kg}$ CDM.

Diet $\mathrm{T}$ differed from $\operatorname{diet} \mathrm{C}$ in that molasses was replaced with 2.01 proprietary urea/molasses supplement containing $390 \mathrm{~g} / 1 \mathrm{CP}, 124 \mathrm{~g} / 1$ urea and $330 \mathrm{~g} / \mathrm{l}$ sugars. Both diets contained an estimated

Table 1 Dry matter and nitrogen degradation characteristics of $\operatorname{diet} \mathrm{C}$

\begin{tabular}{lccc}
\hline \hline & $a(\%)$ & $b(\%)$ & $c($ per h) \\
\hline Dry matter & 46.7 & 41.6 & 0.059 \\
Nitrogen & 47.3 & 46.3 & 0.064 \\
\hline \hline
\end{tabular}

12.6 MJ ME per $\mathrm{kg} C D M$, and supplied a theoretical 3135/3502 $\mathrm{g} \mathrm{MP}$ per day at a calculated ERDP : FME ratio of $8.5 / 10.8$ for diets $C$ and $T$ respectively. $D M$ and nitrogen degradability of diet $C$ were measured in non-lactating dairy cows in situ using the polyester bag technique.

\section{Results}

The degradation characteristics of diet $C$ were determined using the method of Ørskov and McDonald (1979). The values are given in Table 1. Diet $C$ had a large immediately soluble fraction for both DM and nitrogen, the $b$ fraction was extensively degraded in the rumen and the ERDP and digestible undegraded protein (DUP) values of the complete diets at an outflow rate of 0.08 per $h$ were 116 and $34.9 \mathrm{~g} / \mathrm{kg}$ DM respectively.

The effects on DM intake, milk yield, milk composition and milk component yields are shown in Table 2. There were no significant differences between diets in silage intake, milk yield, milk composition or milk component yields.

Blood urea levels, measured on days 4 and 11 were 5.2 and $8.1 \mathrm{mmol} / 1$ (s.e. 0.38 ) and 6.5 and $7.7 \mathrm{mmol} / 1$

Table 2 Total intake ( $k g$ dry matter per day), milk yield $(\mathrm{kg} /$ day $)$, milk composition $(\mathrm{g} / \mathrm{kg})$ and milk component yields $(\mathrm{kg} /$ day $)$

\begin{tabular}{lccc}
\hline \hline & \multicolumn{3}{c}{ Diet } \\
\cline { 2 - 3 } & $\mathrm{C}$ & $\mathrm{T}$ & \\
\hline Total intake & 22.9 & 22.8 & s.e. \\
Milk yield & 40.6 & 39.4 & 0.85 \\
Fat & 34.1 & 33.9 & 0.83 \\
Protein & 28.6 & 29.7 & 1.87 \\
Lactose & 47.4 & 46.8 & 0.57 \\
Fat yield & 1.39 & 1.27 & 0.69 \\
Protein yield & 1.15 & 1.10 & 0.10 \\
Lactose yield & 1.93 & 1.74 & 0.06 \\
\hline \hline
\end{tabular}


(s.e. 0.34) for diets $\mathrm{C}$ and $\mathrm{T}$ respectively and were significantly higher on both occasions for cows given diet $\mathrm{T}$ compared with diet $\mathrm{C}(P<0.001)$.

\section{Conclusions}

For dairy cows giving $40 \mathrm{~kg}$ milk per day, the addition of urea to a diet with a theoretical ERDP : FME ratio below the optimum did not improve DM intake, milk yield, milk composition or milk constituent yield but tended to increase blood urea levels.
References

Agricultural and Food Research Council. 1990. Technical Committee on Responses to Nutrients, report no. 5. Nutritive requirements of ruminant animals: energy. Nutrition Abstracts and Reviews, Series B 60: 729-804.

Agricultural and Food Research Council. 1992. Technical Committee on Responses to Nutrients, report no. 9. Nutritive requirements of ruminant animals: protein. Nutrition Abstracts and Reviews, Series B 62: 787-835.

Ørskov, E. R. and McDonald, I. 1979. The estimation of protein degradability in the rumen from incubation measurements weighted according to rate of passage. Journal of Agricultural Science, Cambridge 92: 499-503. 